\title{
MONITORING COASTLINE CHANGE IN THE RED RIVER DELTA USING REMOTELY SENSED DATA
}

\author{
Nguyen Van Thao ${ }^{{ }^{*}}$, Tran Duc Thanh ${ }^{1}$, Yoshiky Saito ${ }^{2}$ and Chris Gouramanis ${ }^{1}$ \\ ${ }^{1}$ Institute of Marine Environment and Resources-VAST \\ 246 Da Nang, Ngo Quyen, Hai Phong, Viet Nam \\ *E-mail: thaonv@imer.ac.vn \\ ${ }^{2}$ Geological Survey of Japan \\ Received: 15-10-2012
}

\begin{abstract}
This study focuses on the use of remotely sensed data for monitoring coastline changes in the Red River Delta during the 1998 to 2008 period. For the satellite image data processing, the shoreline was defined as the mean sea level on the muddy coast where the tide is the dominant dynamic factor and as the mean high sea level on the sandy coast where the ocean waves are the dominant dynamic factor. A GIS approach was used for the quantitative analysis of coastline change. It was observed that the coastline change in the Red River Delta underwent complicated changes during this 10 year period. In this period, the accretion rate in Red River Delta coastal area was about 10,256ha and the erosion rate was about 542ha. In the Hai Hau and Hau Loc coastal areas, erosion occurred in a large scale and was very intense. Along other coastlines of the Red River Delta, sediment accretion dominated at rates of over 30m/year. These zones of varying erosion and accretion have important implications for coastal zone management in the Red River Delta region.
\end{abstract}

Keywords: Red River Delta, erosion, accretion, coastal zone management, remote sensing, geographic information system.

\section{INTRODUCTION}

Monitoring coastal erosion and accretion using remote sensing data is a good solution to overcome the challenges that traditional monitoring methods face to in coastal environmental management. In assessment of coastal change, in a given period of time, the integration of image data with other geodata into Geographical Information Systems (GIS) is a powerful tool for quantitative spatial data analysis [10].

The Red River Delta coastal zone is about $120 \mathrm{~km}$ long from Do Son to Lach Truong, about $17,000 \mathrm{~km}^{2}$ in area, less than three meters above sea level, and much of it is one meter or less, and houses many important socio-economic and residential areas in the Northern Vietnam. During recent decades, the coastal change in this zone has occurred in a complicated manner. Significant climatic and environmental events can cause sea dykes to be broken and bring terrible disasters to the populous residential areas behind the dykes [11]. Monitoring of the coastal change in the Red River Delta has been conducted previously in a number of studies [1, 5, 6, 8] and comprehensively reviewed by Thanh et al. [9]. However, the results of these studies were neither systematic due to a limitation in the data collected. A recent study [3] used remotely sensed data, published topographic maps and field survey data within a GIS environment to monitor the coastal change in the Red River Delta during the 1930 to 1998 period with reliable results. This study is to continue the monitoring of the coastline 
changes in the Red River Delta for the 1998 to 2008 period using remotely sensed data. This paper recorded changes in the location and magnitude of the accretion and erosion processes affecting the Red River Delta coastline during this period.

\section{MATERIALS AND METHODS}

Main materials for this study include two scenes of SPOT 4 acquired on the $21^{\text {st }}$ December 1998 and $20^{\text {th }}$ March 2008 topographic UTM maps at scales of 1:50,000 and 1:25,000 published in 1998 and tidal data collected from the Vietnam Navy Force. A field survey to characterize the tidal flats was carried out from the $4^{\text {th }}$ to $10^{\text {th }}$ March 2008. This survey measured the height of the flat, the position of the eroded cliffs and the width of the flat. Observations of the surrounding terrain and the direction of the ocean and river currents were conducted and photos and videos were taken. GPS was used to accurately locate of the shoreline at survey time.

Coastline in the study area is identified on satellite images by the combination of satellite image resolution and coastal dynamics and geomorphology. In the areas of strong erosion, such as Hau Loc and Hai Hau, recognized by linear cliffs and beaches, the coastline was defined as the highest tidal level. The highest tidal level coincides with the foot of the cliff and the landward beach boundary. In muddy accreted areas, such as river mouth areas, the coastline was identified as the boundary between the tidal flats and mangrove forests.

SPOT multi-spectral satellite images, with $20 \mathrm{~m}$ spatial resolution and geometrically corrected to
UTM geographic coordinates using the 2000 Vietnam Projection datum and enhanced to better identify the coastline, were used for detecting the coastline. Then extracted data were overlaid in GIS to calculate the difference between the geographic positions of the coastlines [2] and finally to get the area, length and the average rate of erosion or accretion [3] in the following relationship:

$$
\mathrm{R}=\mathrm{A} / \mathrm{L}
$$

Where $\mathrm{R}$ is the average rate of erosion or accretion for the 1998 to 2008 period, A is the area of erosion or accretion (ha), and $\mathrm{L}$ is the length $(\mathrm{km})$ of erosion or accretion. Two kinds of output include the map of the multi-temporal coastlines and erosion/accretion, and the data file of summary statistics of changes in coastline parameters [3]. The assessment of coastline change in Red River Delta is according to scale and intensity of erosion/accretion [3].

\section{RESULTS}

\section{Do Son - Tra Ly coastal part}

In the period from 1998 to 2008 in the Do Son Tra Ly coastal zone, accretion was very strong, both in intensity and scale, along the coast (figure 1) with a total area of accretion reaching 2,900 ha along a $54 \mathrm{~km}$ long coastline at an average rate of about $50 \mathrm{~m}$ per year (table 1). Erosion occurred at two coastal segments in the Thai Do Commune of Thai Thuy District, Thai Binh Province with different intensity and scales. The total eroded area was about 89ha along a $5.86 \mathrm{~km}$ long coastline at an average rate of $11 \mathrm{~m}$ per year (figure 1 ).

Table 1. Erosion/accretion in the Do Son - Tra Ly coastal zone in 1998 - 2008

\begin{tabular}{|c|c|c|c|c|c|c|c|}
\hline Province & District & Commune & $\begin{array}{l}\text { Area } \\
\text { (ha) }\end{array}$ & $\begin{array}{l}\text { Length } \\
\text { (m) }\end{array}$ & $\begin{array}{c}\text { Rate } \\
\text { (m/year) }\end{array}$ & Intensity & Scale \\
\hline \multirow{6}{*}{ Hai Phong } & Kien Thuy & Bang La - Dai Hop & 501.10 & 8,301 & +60.3 & Very strong & Very large \\
\hline & Tien Lang & Vinh Quang - Dong Hung & $1,079.26$ & 13,202 & +81.6 & Very strong & Very large \\
\hline & & & 499.82 & 7,632 & +65.4 & Very strong & Very large \\
\hline & & Thai Thuong & 178.77 & 4,859 & +36.7 & Very strong & Very large \\
\hline & Thai Thuy & & 3.98 & 892 & -4.5 & Medium & Medium \\
\hline & & Thai Do & 84.70 & 4,966 & -17.0 & Very strong & Very large \\
\hline \multirow{2}{*}{ Thai Binh } & & & 470.70 & 12,889 & +36.4 & Very strong & Very large \\
\hline & Tien Hai & Dong Long & 171.23 & 7,164 & +22.5 & Very strong & Large \\
\hline
\end{tabular}

Note: - is erosion, + is accretion 
Monitoring coastline change in the red river ...

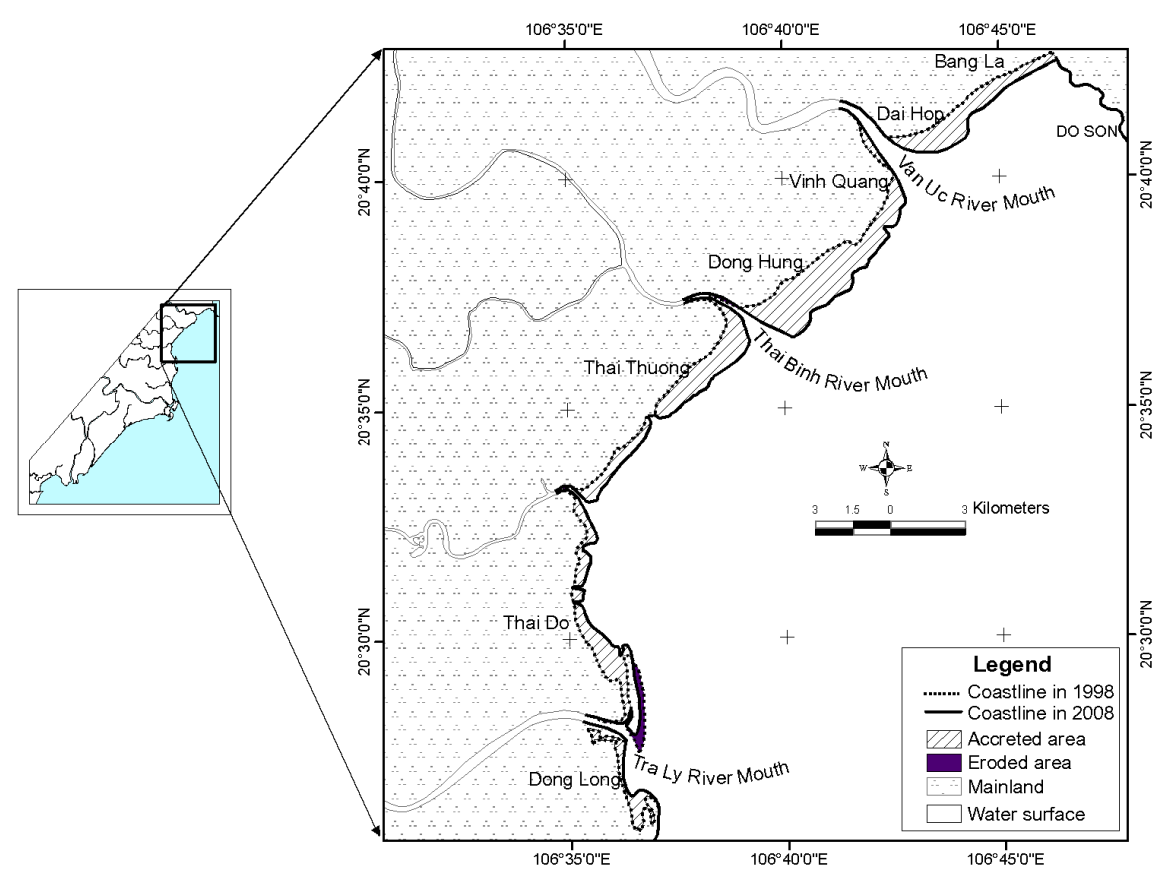

Figure 1. Map of erosion/accretion of Do Son - Tra Ly coastal zone from 1998 to 2008

\section{Ba Lat River Mouth}

Like the Do Son - Tra Ly coastal zone, accretion was very strong, both in intensity and scale, in the area near the $\mathrm{Ba}$ Lat river mouth (figure 2) with total area of about 4,390ha along a $64.3 \mathrm{~km}$ long coastline at an average rate of about $36 \mathrm{~m}$ per year (table 2). There were three coastal segments eroded in the Con Vanh Commune of Tien Hai District, Thai Binh Province and one at the Con Lu Commune of Giao Thuy District, Nam Dinh Province with a strong intensity and a medium scale of erosion. The total eroded area was about $67 \mathrm{ha}$ along a coastline $5.78 \mathrm{~km}$ long at an average rate of about $11.6 \mathrm{~m}$ per year (figure 2).

Table 2. Erosion/accretion in the Ba Lat River mouth in 1998 - 2008

\begin{tabular}{|c|c|c|c|c|c|c|c|}
\hline Province & District & Commune & $\begin{array}{c}\text { Area } \\
\text { (ha) }\end{array}$ & $\begin{array}{l}\text { Length } \\
\text { (m) }\end{array}$ & $\begin{array}{c}\text { Rate } \\
\text { (m/year) }\end{array}$ & Intensity & Scale \\
\hline \multirow{7}{*}{ Thai Binh } & \multirow{7}{*}{ Tien Hai } & Nam Thinh - Nam Phu & 615.53 & 12,308 & +50.0 & Very strong & Very large \\
\hline & & \multirow{6}{*}{ Con Vanh } & 14.72 & 1,426 & +10.2 & Strong & Medium \\
\hline & & & 7.39 & 963 & +7.6 & Medium & Small \\
\hline & & & 46.15 & 2,644 & +17.4 & Strong & Medium \\
\hline & & & 5.85 & 527 & -11.2 & Very strong & Medium \\
\hline & & & 4.33 & 661 & +6.4 & Medium & Small \\
\hline & & & 29.87 & 1,720 & -17.2 & Very strong & Medium \\
\hline Nam Dinh & Giao Thuy & Con Ngan - Con Lu & 2.80 & 1,067 & -6.4 & Strong & Medium \\
\hline
\end{tabular}

Note: - is erosion, + is accretion 
Nguyen Van Thao, Tran Duc Thanh, ...

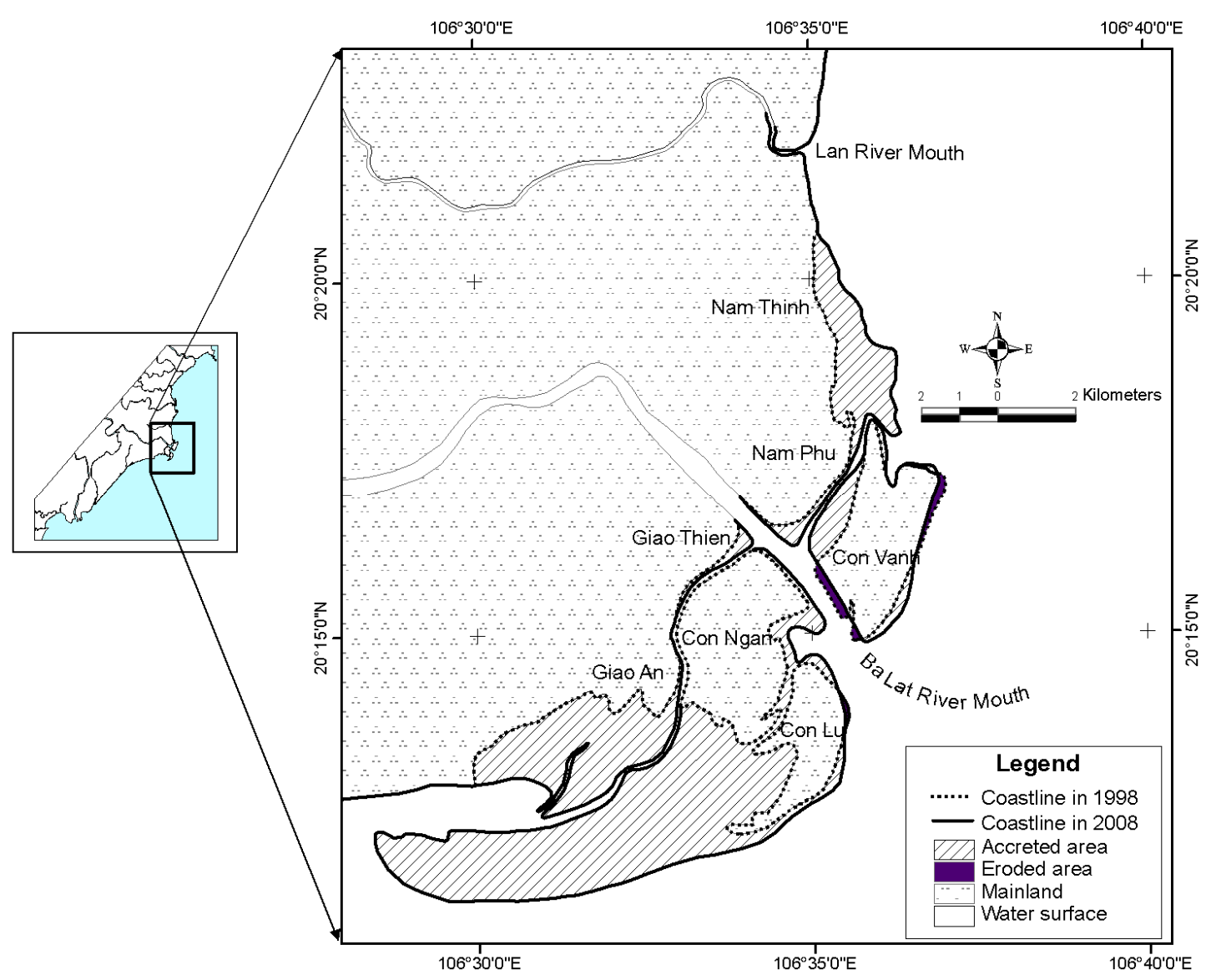

Figure 2. Map of erosion/accretion of Ba Lat River mouth in 1998 - 2008

\section{So - Lach Giang coastal area}

Unlike the two mentioned parts, erosion was strong, both in intensity and scale, along the So Lach Giang coastal area (figure 3). The total eroded area is about $253 \mathrm{ha}$ along a coastline $20.3 \mathrm{~km}$ long at an average rate of about $11 \mathrm{~m}$ per year (table 3 ). Two sections of coastline were accreted, one at the Giao Lam Commune of Giao Thuy District and one at the Hai Loc Commune of Hai Hau District, Nam Dinh Province, both with a strong intensity and a medium scale of accretion. The total accreted area was about 140ha along a $7.834 \mathrm{~km}$ long coastline at an average rate of $14 \mathrm{~m}$ per year (figure 3 ).

Table 3. Erosion/accretion in the So - Lach Giang coastal area in 1998 - 2008

\begin{tabular}{|c|c|c|c|c|c|c|c|}
\hline Province & District & Commune & $\begin{array}{l}\text { Area } \\
\text { (ha) }\end{array}$ & $\begin{array}{l}\text { Length } \\
\text { (m) }\end{array}$ & $\begin{array}{c}\text { Rate } \\
\text { (m/year) }\end{array}$ & Intensity & Scale \\
\hline \multirow{7}{*}{ Nam Dinh } & \multirow[t]{4}{*}{ Giao Thuy } & Giao Lam & 132.94 & 7,116 & +18.6 & Strong & Large \\
\hline & & \multirow{2}{*}{ Hai Loc } & 4.88 & 728 & -6.6 & Strong & Medium \\
\hline & & & 6.78 & 719 & +9.4 & Medium & Small \\
\hline & & Hai Ly & 103.20 & 4,539 & -22.6 & Very strong & Large \\
\hline & \multirow{3}{*}{ Hai Hau } & \multirow{2}{*}{ Hai Chinh } & 20.8 & 2,505 & -8.2 & Strong & Large \\
\hline & & & 17.44 & 2,489 & -7.1 & Strong & Large \\
\hline & & Thinh Long & 107.23 & 10,101 & -10.7 & Very Strong & Very large \\
\hline
\end{tabular}

Note: - is erosion, + is accretion 


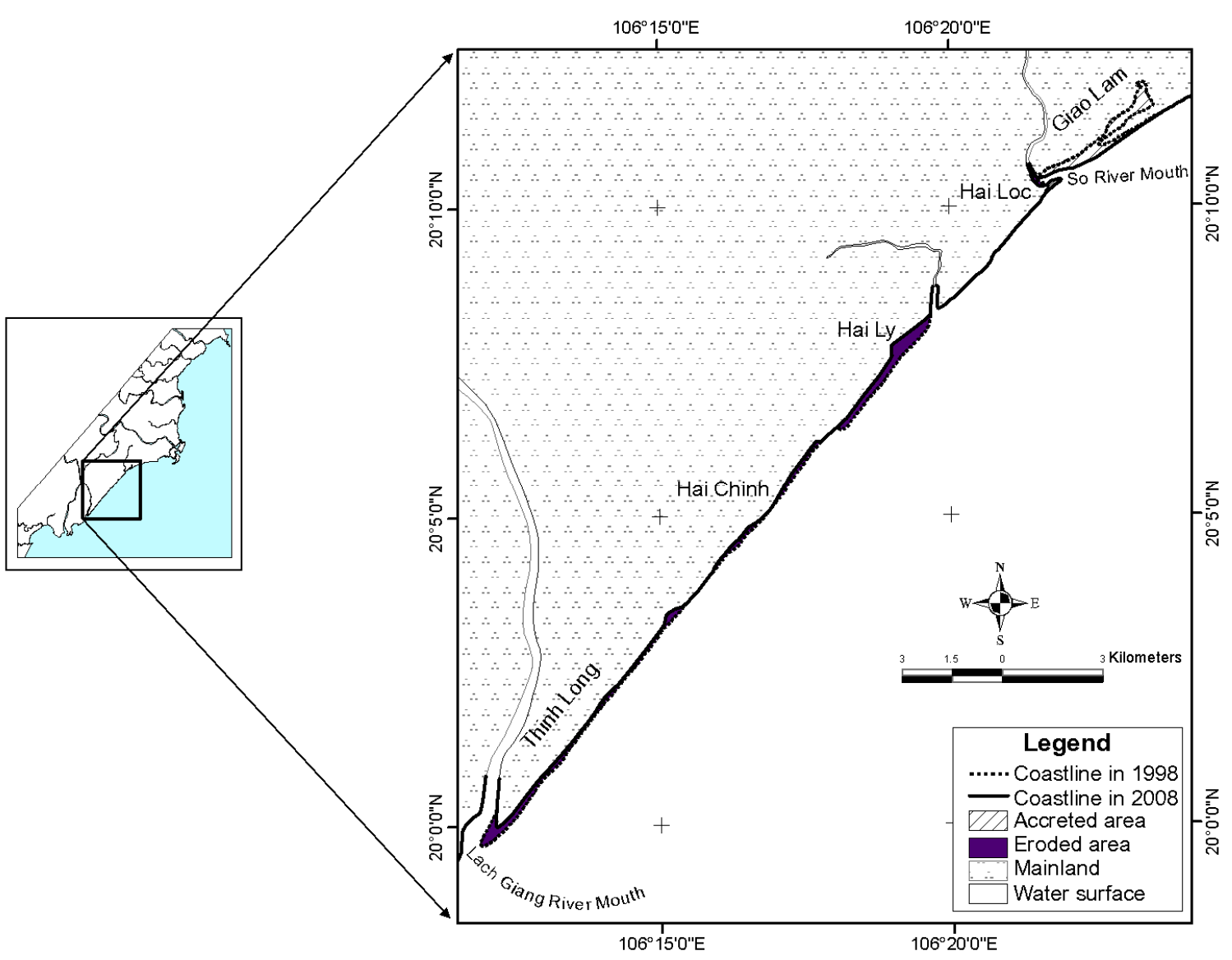

Figure 3. Map of erosion/accretion of So - Lach Giang coastal zone in 1998 - 2008

\section{Lach Giang - Lach Truong coastal area}

Accretion was very strong both in intensity and scale along the Lach Giang - Lach Truong coastal area from 1998 to 2008 (figure 4). The total accreted area extends about 2,828 ha along a $46.2 \mathrm{~km}$ long coastline at an average rate of about $37.5 \mathrm{~m}$ per year (table 4). Three coastal segments were also eroded at the Nghia Phuc and Rang Dong Commune of Nghia Hung District, Nam Dinh Province and one at the Hau Loc Commune of Ngu Loc District, Thanh Hoa Province with a strong intensity and a large scale. The total eroded area was about 133 ha along an $11.3 \mathrm{~km}$ coastline at an average rate of $10.1 \mathrm{~m}$ per year (figure 4).

Table 4. Erosion/accretion in the Lach Giang - Lach Truong coastal area in 1998 - 2008

\begin{tabular}{|c|c|c|c|c|c|c|c|}
\hline Province & District & Commune & $\begin{array}{l}\text { Area } \\
\text { (ha) }\end{array}$ & $\begin{array}{c}\text { Length } \\
\text { (m) }\end{array}$ & $\begin{array}{c}\text { Rate } \\
\text { (m/year) }\end{array}$ & Intensity & Scale \\
\hline \multirow{4}{*}{ Nam Dinh } & \multirow{4}{*}{ Nghia Hung } & \multirow{2}{*}{ Nghia Phuc } & 9.28 & 1,379 & -6.5 & Strong & Medium \\
\hline & & & 8.05 & 1,481 & +5.4 & Medium & Medium \\
\hline & & \multirow{2}{*}{ Rang Dong } & $2,114.60$ & 23,436 & +90.2 & Very strong & Very large \\
\hline & & & 28.55 & 2,572 & -11.2 & Very strong & Large \\
\hline \multirow{2}{*}{ Ninh Binh } & Kim Son & Binh Minh & 517.60 & 15,406 & +33.7 & Very strong & Very large \\
\hline & Nga Son & Nga Thuy & 139.94 & 3,384 & +41.2 & Very strong & Medium \\
\hline \multirow{2}{*}{ Thanh Hoa } & \multirow{2}{*}{ Hau Loc } & Da Loc & 47.70 & 2,801 & +17.0 & Strong & Medium \\
\hline & & Ngu Loc & 95.15 & 7,360 & -12.8 & Very strong & Very large \\
\hline
\end{tabular}

Note: - is erosion, + is accretion 


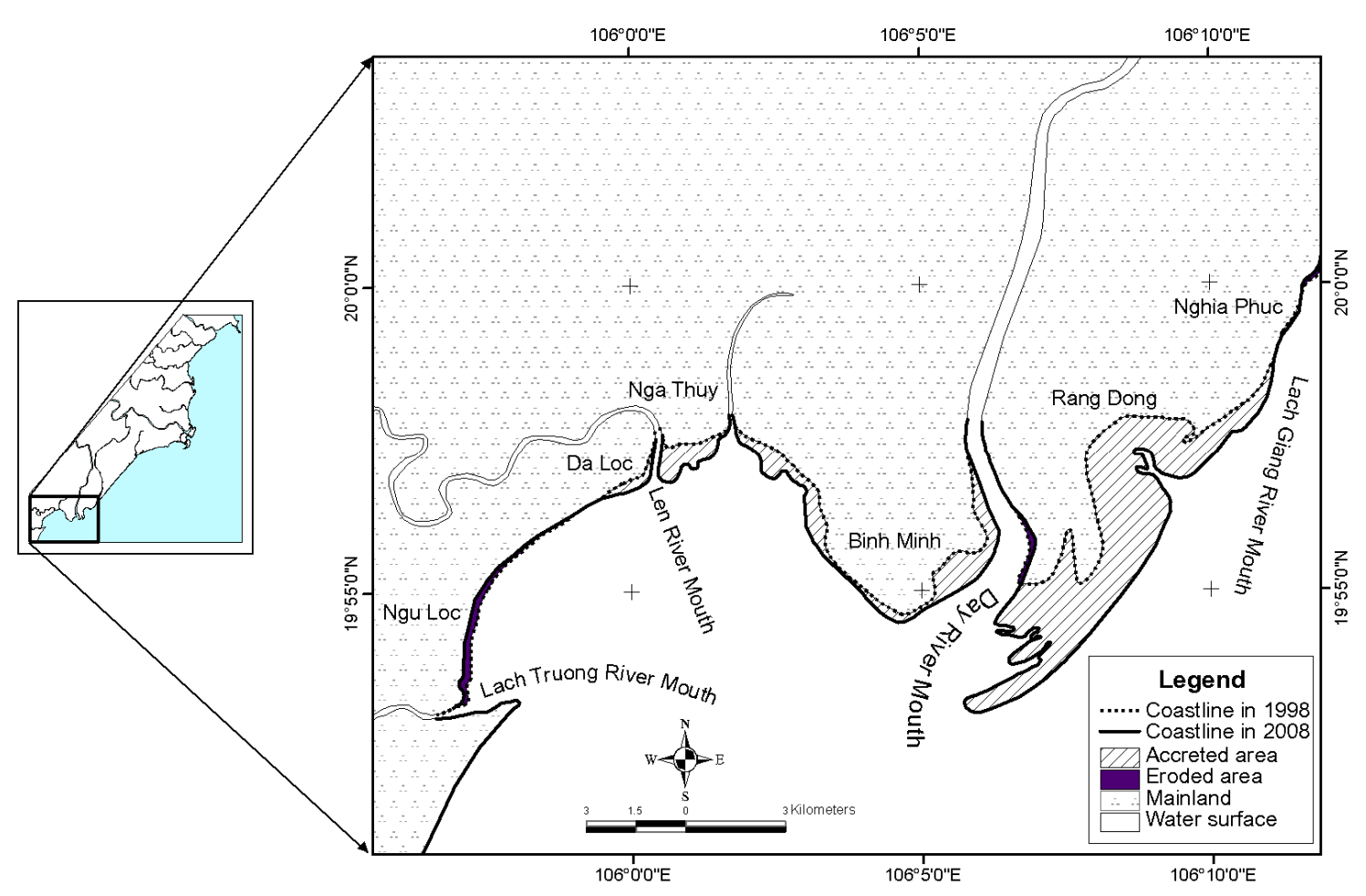

Figure 4. Map of erosion/accretion of Lach Giang - Lach Truong coastal zone in 1998 - 2008

\section{DISCUSSION}

\section{Coastline change in the Red River Delta in 1998 - 2008}

Coastal accretion in $1998-2008$ dominated the coastal areas of the Kien Thuy, Tien Lang, Thai Thuy, Tien Hai, Nghia Hung and Kim Son Districts with a very strong scale and intensity. The total accreted area in this southern section of the Red River Delta was about 10,256ha along a 172km long coastline at an average rate of $34 \mathrm{~m}$ per year. Compared to the other periods [3], the scale of accretion during the 1998 to 2008 period has doubled (table 4).

The coastal area from the Kien Thuy District to the northern part of the Thai Thuy District was with accretion rates of $60 \mathrm{~m}$ to $80 \mathrm{~m}$ per year recorded in the areas surrounding the Van Uc and Thai Binh river mouths. Sedimentation in this area was occurring symetrically along the coastlines between these river mouths suggesting that longshore currents were not strongly influencing coastline change.

The northern part of the Tra Ly river mouth was under erosion at the offshore sandy floor, but the coastline was moving seaward. The Ba Lat river mouth area showed a complex history of coastline change with minor zones of erosion, on the eastern shore and within the estuary at Con Vanh and the eastern shore at Con Lu. Very strong intensity and scale of accretion were within the $\mathrm{Ba}$ Lat river mouth and to the north and south of it. Dien et al. [3] showed that parts of this river mouth were accreting at rates of $100 \mathrm{~m}$ per year in period from 1990 to 1998 , and in this study it is indicated that the rate keeps continuing.

Asymmetric accretion was occurring in the Day river mouth with the north-eastern shore at a rate $(90 \mathrm{~m}$ per year) that was approximately three times faster than that in the south-western shore (34m per year). Dien et al. [3] showed that parts of this coastline were on average accreting at rates of about $100 \mathrm{~m}$ per year in 1990 - 1998. This asymmetry may be due to the accumulation of sediments from Dai Giang River transported south by longshore drift and deposited on the northern shore of the Day river mouth.

In the coastal zone from Do Son to Lach Truong, two coastal sections were in strong erosion in 1998 - 2008, including the Hai Hau coast and the Hau Loc coast. 
Dien et al. [3] showed that the Hai Hau coast was eroded in parts since at least 1930 at a rate of 5 to $10 \mathrm{~m}$ per year. Between 1990 and 1998, the local government built a series of dykes using unconsolidated rocks along the coastline embankment in an effort to reduce erosion. The coastal section from Hai Chinh to Thinh Long on the Hai Hau coast was eroded at a high rate, reaching 20 to $30 \mathrm{~m}$ per year at some sites [3]. During the period from 1998 to 2008, this area continued to be eroded at a rate of $11 \mathrm{~m}$ per year, with some of the coastal sections, such as at Thinh Long and Hai Ly, being eroded at a rate of over $20 \mathrm{~m}$ per year. In the future, it is predicted that this coast will continue to be eroded even though dykes have been built along the coast.

The erosion of the Hau Loc coast has persisted since 1930. From 1990 to 1998 , it occurred with a stronger intensity and larger scale in comparison with previous periods [3]. Although this coast has had unconsolidated stone dykes built, the erosion has continued in this period at an average rate of $10 \mathrm{~m}$ per year. In the Ngu Loc coastal section, the rate of erosion was most intensive, reaching $20 \mathrm{~m}$ per year in this period. During 1998 to 2008, the Hau Loc coast was eroded at a rate of over $10 \mathrm{~m}$ per year along an $11.3 \mathrm{~km}$ coastline. In the future, this coastline will continue to be eroded, although this coast has had stone dykes constructed.

Erosion along the Hai Hau and Hau Loc coastlines can be attributed to the prevalent southwestward longshore currents at depths of less than $5 \mathrm{~m}$ and southward currents between 10 and 30m depth [4]. Duc et al. [4] described the Hai Hau coastline as behaving like a "high-wave energy coast" (p. 564), and the continued high rates of erosion, similar oceanic current systems and the geomorphology of the Hau Loc coastline indicates a similar environment.

Table 5. Coastline change in the Red River Delta in different periods

\begin{tabular}{|c|c|c|c|c|c|c|c|c|c|}
\hline Coastal part & \multicolumn{2}{|c|}{1930 to 1965} & \multicolumn{2}{|c|}{1965 to 1990} & \multicolumn{2}{|c|}{1990 to 1998} & \multicolumn{2}{|c|}{1998 to 2008} & Status \\
\hline \multirow{2}{*}{$\begin{array}{l}\text { Do Son to } \\
\text { Tra Ly }\end{array}$} & 9.2 & 25,120 & 9.1 & 19,070 & 7.5 & 1,800 & 10.7 & 5,858 & Erosion \\
\hline & 21.8 & 24,600 & 41.2 & 27,700 & 27.1 & 33,400 & 50 & 54,000 & Accretion \\
\hline $\begin{array}{l}\text { Ba Lat river } \\
\text { mouth }\end{array}$ & 11.3 & 9,500 & 15.4 & 9,300 & 0 & 0 & 11.6 & 5,780 & Erosion \\
\hline \multirow{2}{*}{$\begin{array}{l}\text { So to Lach } \\
\text { Giang }\end{array}$} & 4.6 & 8,600 & 9.6 & 19,500 & 15.6 & 17,200 & 11 & 20,300 & Erosion \\
\hline & 13.9 & 4,200 & 2.5 & 4,100 & 0 & 0 & 14 & 7,835 & Accretion \\
\hline \multirow{2}{*}{$\begin{array}{l}\text { Lach Giang to } \\
\text { Lach Truong }\end{array}$} & 10 & 2,160 & 8.1 & 7,100 & 15.6 & 5,500 & 10.1 & 11,300 & Erosion \\
\hline & 56.1 & 32,600 & 59 & 34,000 & $>100$ & 29,100 & 37.5 & 46,000 & Accretion \\
\hline
\end{tabular}

\section{Causes of coastline change in the Red River Delta}

\section{Natural causes}

The coastline change in the Red River Delta coastal area is complex in scale and intensity, highly dependent on the geomorphologic characteristics of each coastal section, riverine and oceanic dynamics. Dien et al. [3] found that in this coastal area, sites near river mouths are undergoing accretion and ones distant from major river mouths are undergoing erosion. The same broad pattern is apparent from the present study.
Thanh et al. [9] showed that where tectonic subsidence of the coastal and offshore region of the Red River Delta is accompanied by sediment deposition from river mouths, deltaic accretion occurs. At sites distant from river mouths, the tectonic subsidence and the resultant eustatic sea level rise and longshore oceanic currents results in the erosion of the coastal zone. In Red River Delta, the tectonic subsidence is dominating, but the accretion is still strong, thank to the high rate of compensative deposition. In a certain condition of locally deficient sediments, the total subsidence of both tectonic sink and eustatic rise of sea level 
become the cause of coastal erosion. The lack of sediments in coastal zone and estuaries in the present time mainly concerns the water uses in the catchment, for example damming and irrigation. This can be demonstrated by influence of Hoa Binh Dam on the upstream of Red River. The construction of the Dam was completed in 1989 and every year, the volume of some 40 million sediments accounting for 40 percent of total sediment discharge of Red Rive are trapped in the reservoir bottom [9]. However, the direct cause of coastal erosion belongs to the meteoro-hydrology factors such as the actions of wave, current, typhoon, and sea level rise, including monsoon and storm surges. Recently, the turbulence of these factors by the global warming has caused unusually coastal erosion. The observed data in some stations show the sea level rise of $2-3 \mathrm{~mm} /$ year in Red River Delta [9].

Some extensive studies of the sedimentation and water dynamics of the Ba Lat Estuary [9, 12, $13,14]$ in 2005 - 2007 showed a complex interplay between the tidal regime, seasonal and extreme climatic events, and the velocity and bedload of the river plume were the dominant features controlling the morphology of the estuary. In particular, the avulsion of the former Ba Lat channel in 1971, $10 \mathrm{~km}$ to the south, has had a major influence on the sedimentation in this estuary with increased rates of accretion at the site of the present river mouth and low rates of accretion and erosion near the former river mouth.

\section{Human activities}

During 1992 to 2008 period, one of the main causes of the increase in scale and intensity of the accretion is due to human activities to exploit directly resources in the coastal wetland area. For example, between 1992 and 2002, the area converted to aquaculture ponds in the Xuan Thuy and Tien Hai region was increased by factors of 9 and 5, respectively [7]. The 1992 to 2002 period also recorded an increase in the area of mangrove plantation in the Xuan Thuy and Tien Hai regions with the increases of $7 \mathrm{~km}^{2}$ in each region [7]. Thao [11] reported that over 3,000ha of aquaculture ponds were established and about 2,500ha of mangroves were planted in the tidal flat areas of this section of the Red River Delta coastal zone between 1998 and 2008. Aquaculture ponds and mangrove plantations help stabilize sedimentation in coastal zones by minimizing remobilization of the sediment. Thus, with continued development of aquaculture ponds and plantation of mangroves along these accreted shorelines, there is strong evidence to suggest that the rates of accretion in these regions will continue at the present rates.

It is still unclear that human activities such as construction of channels, dykes and dams have impacted on the coastline change [4], although Seto and Fragkias [7] and Thao [11] showed that aquaculture pond development and plantation of mangroves could facilitate coastline accretion. Thanh et al. [9] indicated that a range of human activities, such as river damming, irrigation practices, dyke building, river channel dredging, mangrove destruction and mining practices, would played a significant role in the observed coastline changes. The data presented here suggest that the construction of unconsolidated stone dykes in the Hai Hau and Hau Loc coastal zones has not impacted upon the erosion rates in these areas.

From Dien et al. [3] and the results of the study, it is clear that the processes causing the erosion and accretion are continuing to affect the coastline morphology in the Red River Delta.

\section{CONCLUSION}

Remotely sensed data has been used to monitor coastline change in Red River Delta in period from 1998 to 2008. The results of coastline change assessment show that the coastline change has occurred in a complicated manner. The scale and intensity of accretion in this period were higher than previous periods with about 10,256ha accreted along a $172 \mathrm{~km}$ long coastline and at an average rate of $34 \mathrm{~m}$ per year. Erosion has also occurred in some regions of the Red River Delta, at a scale and intensity smaller than previous periods. The total eroded area was about 542ha along a $43.2 \mathrm{~km}$ coastline at an average rate of $10.1 \mathrm{~m}$ per year.

Remote sensing data and GIS technologies have presented useful information on the coastal erosion of the Red River Delta. In this study, the coast was defined as the mean sea level and mud-sandy coasts where tidal dynamics dominated, and as the high sea level on sandy coasts where wave dynamics dominated. Regular monitoring coastal erosion by remote sensing and GIS is an important tool that needs to be utilized for better management of the coastal environment. 
Acknowledgements: We would like to thank the Project "Argumentation of Science and Technology on the Integrated Management and Sustainable Development in the Coastal zone of Western Tonkin Gulf, Viet Nam, coded KC.09-13/06-10" for supporting the satellite images, and the Project "Mega - Delta Watching In Asia" for helping the procedures of publication.

\section{REFERENCES}

1. Cu, N. D., Hoi, N. C., Thanh, T. D. and Lan, T. $D ., 1993$. Tidal wetland inventory in the coast zone of Red River Delta. Project report reserved at Institute of Marine Environment and Resources, pp. 62-66.

2. Delsol, J. P., 1997. Integration of Remote Sensing and GIS. STAR, AIT, pp. 120-130.

3. Dien, T. V., Thanh, T. D., Thao, N. V., 2003. Monitoring Coastal Erosion in Red River Delta, Viet Nam - A Contribution from Remote Sensing Data. Asian Journal of Geoinformatics 3, pp. 73-78.

4. Duc, D. M., Nhuan, M. T., Ngoi, C. V., Nghi, T., Tien, D. M., Van Weering, Tj. C. E. and Van Den Bergh, G. D., 2007. Sediment distribution and transport at the nearshore zone of the Red River delta, Northern Vietnam. Journal of Asian Earth Sciences 29, pp. 558-565.

5. Huy, D. V., 1999. Morphological dynamic characteristics and sustainable development orientation for Hai Phong Ha Long coastal zone. Marine Environment and Resources, Tom VI, Vietnam Science \& Technology Publish House, pp. 46-49.

6. Ninh, P. V. and Hong, L. X., 2000. Status of coastline erosion in Viet Nam. Presented paper at technical workshop on erosion and sedimentation in Viet Nam coastal zone, Ha Noi, May 2000.

7. Seto, K. S. and Fragkias, M., 2007. Mangrove conversion and aquaculture development in Vietnam: A remote sensing-based approach for evaluating the Ramsar Convention on Wetlands. Global Environmental Change 17, pp. 486-500.

8. Thanh, T. D., Cu, V. D. and Hoi, N. C., 1998. Coastline deformation characteristics and solution for preventing coastal erosion in Cat Hai island, Vietnam. Marine Environment and Resources, Tom IV, Vietnam Science \& Technology Publish House, pp. 35-38.

9. Thanh, T. D., Saito, Y., Huy, D. V., Cu, N. H. and Chien, D. D., 2005. Coastal erosion in Red River Delta: Current Status and Response. In Z. Y. Chen, Y. Saito, S.L. Goodbred, Jr. eds., Mega-Deltas of Asia: Geological Evolution and Human Impact, China Ocean Press, Beijing, pp. 98-106.

10. Thao, N. V., 2005. Monitoring and Predicting the Thuan An Inlet Movement with Remote Sensing and GIS Technology. Marine Environment and Resources, Tom XI, Viet Nam Science \& Technology Publish House, pp. 241-256.

11. Thao, N. V., 2008. Mapping landuse/cover and detecting the landuse/cover changes in the coast of Red River Delta by using remotely sensed data and GIS technology. Project report reserved at the Institute of Marine Environment and Resources, pp. 18-23.

12. Van Den Bergh, G. D., Boer, W., Schaapveld, M. A. S., Duc, D. M. and Van Weering, Tj. C. $E$., 2007. Recent sedimentation and sediment accumulation rates of the Ba Lat prodelta (Red River, Vietnam). Journal of Asian Earth Sciences 29, pp. 545-557.

13. Van Maren, D. S. and Hoekstra, P., 2005. Dispersal of suspended sediments in the turbid and highly stratified Red River plume. Continental Shelf Research 25, pp. 503-519.

14. Van Maren, D. S., 2007. Water and sediment dynamics in the Red River mouth and adjacent coastal zone. Journal of Asian Earth Sciences 29, pp. 508-522. 


\title{
GIÁM SÁT BIẾN ĐỘNG BỜ BIỂN CHÂU THỔ SÔNG HỒNG SỬ DỰNG DỬ LIỆU VIẼ̃N THÁM
}

\author{
Nguyễn Văn Thảo ${ }^{1}$, Trần Đức Thạnh ${ }^{1}$, Yoshiky Saito ${ }^{2}$ và Chris Gouramanis ${ }^{1}$
}

${ }^{1}$ Viện Tài nguyên và Môi trường biển-Van Hàn lâm Khoa học và Công nghệ Việt Nam

\author{
${ }^{2}$ Cục Địa chất Nhật Bản
}

TÓM TĂT: Nghiên cưu này sủ dụng dũ liệu viễn thám để giám sát biến động bò̀ biển châu thổ sông Hồng tù năm 1998 đến 2008. Để xư lý dư liệu ảnh vệ tinh, đường bò̀ biển được các định trùng mục biển trung bình trên đới bò̀ bùn cát nơi thủy triều là yếu tố động lực thống trị và mưc biển cao trên đới bò̀ cát nơi sóng là yếu tố động lục thống trị. Công cụ GIS được sủ dụng để phân tích định lương thay đổi đường bò̀ biển. Kết quả nghiên cứu chi ra rằng, đường bò̀ biển châu thổ sông Hồng thay đổi phức tạp trong suốt 10 năm qua, khoảng 10.256ha đã được bồi tụ và xói lở khoảng 542ha. Bờ biển khu vục Hải Hậu và Hộc Lộc xói lở diễn ra với qui mô lớn và cuờng độ rất mạnh. Ở các đoạn bờ khác của châu thổ sông Hồng, xu thế bồi tụ là thống trị với tốc độ trên $30 \mathrm{~m} / \mathrm{năm}$. Các vùng xói lở và bồi tu là địa chi quan trong trong quản lý đới bờ ở châu thổ sông Hồng.

Tù khóa: Châu thổ sông Hồng, xói lở, bồi tụ, quản lý đới bò̀ biển, viễn thám, hệ thông tin địa lý. 